\title{
Measuring social learning in participatory approaches to natural resource management
}

Citation for published version (APA):

Van der Wal, M., de Kraker, J., Offermans, A., C, K., Kirschner, P. A., \& M, I. (2014). Measuring social learning in participatory approaches to natural resource management. Environmental Policy and Governance, 24(1), 1-15. https://doi.org/10.1002/eet.1627

Document status and date:

Published: 01/01/2014

DOI:

10.1002/eet.1627

Document Version:

Publisher's PDF, also known as Version of record

Document license:

Taverne

Please check the document version of this publication:

- A submitted manuscript is the version of the article upon submission and before peer-review. There can be important differences between the submitted version and the official published version of record.

People interested in the research are advised to contact the author for the final version of the publication, or visit the DOI to the publisher's website.

- The final author version and the galley proof are versions of the publication after peer review.

- The final published version features the final layout of the paper including the volume, issue and page numbers.

Link to publication

\footnotetext{
General rights rights.

- You may freely distribute the URL identifying the publication in the public portal. please follow below link for the End User Agreement:

www.umlib.nl/taverne-license

Take down policy

If you believe that this document breaches copyright please contact us at:

repository@maastrichtuniversity.nl

providing details and we will investigate your claim.
}

Copyright and moral rights for the publications made accessible in the public portal are retained by the authors and/or other copyright owners and it is a condition of accessing publications that users recognise and abide by the legal requirements associated with these

- Users may download and print one copy of any publication from the public portal for the purpose of private study or research.

- You may not further distribute the material or use it for any profit-making activity or commercial gain

If the publication is distributed under the terms of Article $25 \mathrm{fa}$ of the Dutch Copyright Act, indicated by the "Taverne" license above, 


\title{
Measuring Social Learning in Participatory Approaches to Natural Resource Management
}

\author{
Merel van der Wal, ${ }^{1 *}$ Joop De Kraker, ${ }^{1}$ Astrid Offermans, ${ }^{2}$ Carolien Kroeze, ${ }^{1,3}$ \\ Paul A. Kirschner ${ }^{4}$ and Martin van Ittersum ${ }^{5}$ \\ ${ }^{1}$ Open Universiteit, School of Science, Heerlen, The Netherlands \\ ${ }^{2}$ Maastricht University, International Centre for Integrated Assessment and Sustainable Development, \\ Maastricht, The Netherlands \\ ${ }^{3}$ Wageningen University, Environmental Systems Analysis, Wageningen, The Netherlands \\ ${ }^{4}$ Open Universiteit, Centre for Learning Sciences and Technologies, Heerlen, The Netherlands \\ ${ }^{5}$ Wageningen University, Plant Production Systems, Wageningen, The Netherlands
}

\begin{abstract}
The role of social learning as a governance mechanism in natural resource management has been frequently highlighted, but progress in finding evidence for this role and gaining insight into the conditions that promote it are hampered by the lack of operational definitions of social learning and practical methods to measure it. In this article, we present a simple and flexible method to measure social learning, whether it has occurred and to what extent, among stakeholders in natural resource management. The method yields measurements of social learning that are visual, quantitative and qualitative. First, we elaborate our definition of social learning as a convergence of perspectives and outline how stakeholder perspectives in natural resource management can be described with Cultural Theory. Next, we provide a generic description of the method, followed by two examples illustrating its application to the domains of water and land management. Finally, we discuss relative strengths and weaknesses of the method and how it could be applied to improve our understanding of factors that contribute to social learning. Copyright (C) 2013 John Wiley \& Sons, Ltd and ERP Environment
\end{abstract}

Received 17 December 2012; revised 7 September 2013; accepted 24 September 2013

Keywords: social learning; Cultural Theory; natural resource management; climate change; adaptation

\section{Introduction}

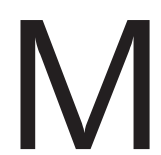

ANY OF THE CURRENT ISSUES IN THE MANAGEMENT OF NATURAL RESOURCES CAN BE QUALIFIED AS 'WICKED' OR 'unstructured' problems (Hisschemöller and Hoppe, I995; Rittel and Webber, I973). These are complex and dynamic multi-actor problems, characterized by structural uncertainties in knowledge and a diversity of perspectives on what the problem actually is and how it should be solved. A typical example concerns adaptation of natural resource management to climate change (Adger et al., 2007). To cope with such problems, participatory approaches that involve stakeholders in the development of integrated solutions have become popular (Reed, 2008). The expected benefits of such a participatory approach can be summarized as (I)

*Correspondence to: Merel van der Wal, Open Universiteit, School of Science, Heerlen, The Netherlands. E-mail: merel.vanderwal@ou.nl 
improving the quality of the solutions by including relevant non-scientific sources of knowledge and experience, (2) enhancing the relevance, legitimacy and credibility of the solutions by accounting for the diversity of perspectives among the stakeholders and (3) widening the basis of support for the implementation of the solutions. In this context, social learning of stakeholders is increasingly seen as a key component (Muro and Jeffrey, 2008; Reed et al., 20I0). Social learning, as we define it, concerns a convergence of stakeholder perspectives on the problem and possible solutions (De Kraker et al., 20II). It supposedly creates the basis for integrated solutions that require collective support and/or concerted action of multiple stakeholders (Röling, 2002), and its potential role as a governance mechanism in natural resource management and climate adaptation has been frequently highlighted over the past decade (see, e.g., Blackmore, 2007; Bouwen and Taillieu, 2004; Collins and Ison, 2009a; Pahl-Wostl et al., 2007). However, so far there is only limited empirical evidence of the actual contribution of social learning to participatory management of natural resources, and better understanding is needed of how social learning can be facilitated to achieve the desired outcomes (Muro and Jeffrey, 2008). Progress in finding evidence for the occurrence and contribution of social learning and gaining insight into the conditions that promote it are hampered by the lack of clear, operational definitions of social learning and practical and reliable methods to measure it in the context of participatory approaches (Reed et al., 2010).

In this article, we present a simple and flexible method to measure social learning, whether it has occurred and to what extent, among stakeholders in natural resource management. First, we elaborate our definition of social learning as a convergence of perspectives and outline how stakeholder perspectives in natural resource management can be described with Cultural Theory (Buck, I989). Next, we provide a generic description of the method, followed by two examples illustrating its application to the domains of water and land management. Finally, we

discuss the relative strengths and weaknesses of the presented method and how it could be applied in combination with in-depth analysis of the communicative interactions between stakeholders, to improve our understanding of the process features and context factors that contribute to social learning.

\section{A Method to Measure Social Learning}

\section{Social Learning as a Convergence of Perspectives}

We define social learning - in the context of a participatory approach to a complex problem with multiple stakeholders - as a convergent change in the stakeholders' perspectives on the problem and its possible solutions and risks, as well as on their own and the other stakeholders' position and responsibility with regard to solving the problem (De Kraker et al., 20II). Our definition implies a focus on the social-cognitive dimension of social learning, which is common in the environmental and natural resource management literature (Muro and Jeffrey, 2008; Reed et al., 2010; Schusler et al., 2003; Van Bommel et al., 2009). Changes in the social-relational dimension such as development of trust, improved communication and better working relations (Mostert et al., 2007; Pahl-Wostl and Hare, 2004), and changes in stakeholders' behaviour and actions (Collins and Ison, 2009b), are outside the scope of our definition and measurement approach.

As Reed et al. (2010) observed, in the natural resource management literature, clear and distinctive definitions of social learning are often lacking. As a consequence, substantive evidence of social learning is rarely provided, which hinders progress in understanding of the factors that promote social learning. We defined social learning with the explicit aim to make it measurable, and our definition is in line with the proposal of Reed et al. (2010) to define social learning as (I) a change in understanding in individuals that (2) goes beyond the individual and (3) occurs through social interactions between actors in a social network. Reed et al. (2010) use the term 'understanding', whereas we chose 'perspective', but in both cases the term refers to the cognitive dimension of learning and encompasses not just knowledge but also goals, values, norms and beliefs. More precisely, in operational terms, we understand an individual's perspective to be a set of concrete beliefs about a complex problem, based on his or her knowledge, goals, values, norms and causal beliefs. These concrete beliefs pertain to the nature of the problem, the risks involved, the feasibility of possible solutions and the distribution of responsibilities to solve the problem. 
Changes in these concrete beliefs are understood to originate from changes in the underlying convictions. In the learning literature this is commonly known as 'double loop learning', in contrast to 'single loop learning' which concerns only changes in 'technical' knowledge and beliefs, e.g. about the effectiveness of certain actions. The concepts of single- and double-loop learning were coined Argyris and Schön (I978) and refer to the feedback loops in a learning process. In single-loop learning there is only one loop of error correction, i.e. between actions and their outcomes. Actions are changed when they do not have the desired outcomes, without questioning or altering the existing framework of goals and causal beliefs underlying the actions. In double-loop learning, a second feedback loop is added when the perceived range of options does not result in desired outcomes. In this feedback loop, the underlying frame of goals, values, norms and beliefs is included in the learning process. Social learning, as defined above, can thus be seen as double-loop learning in the context of a group and as a consequence of the social interactions within that group. It refers specifically to convergent and not to divergent changes in perspective, in line with the original conception of social learning as learning by observing and imitating others (Bandura, I974).

Concerning the interactive processes that bring about social learning, the literature often points out the importance of collectively going through the loops in a learning process. For example, McCrum et al. (2009) refer to this as collective action and reflection, and Jiggins et al. (2007) as shared, experiential learning, amplified by facilitated communication and dialogue. In other words, individual perspectives may change when expectations are not met by observations, and this change may be convergent at group level, when the members of the group make their expectations explicit and exchange their views, and reflect jointly on new information and possible discrepancies with initial expectations ('surprises'). Whether such interactions between stakeholders do result in social learning depends on a broad range of conditions, including case-related factors, such as urgency, convergence of interests, mutually felt positive interdependence and trust, limited risk and balance of power among the stakeholders and a supportive institutional context, as well as a variety of process-related factors, such as balanced stakeholder selection, effective leadership or facilitation, space for reflection, safe and informal environment, and transparency (Aarts and Van Woerkum, 2002; Leeuwis, 2002; Mostert et al., 2007; Van Bommel et al., 2009; Wildemeersch, 2007).

\section{Describing Perspectives with Cultural Theory}

In the previous section we have elaborated our definition of social learning as a convergent change in perspectives. According to this definition, measurement of social learning requires a method to measure perspectives as well as change in perspectives and convergence. The method we present in this article is based on the work of Offermans and Valkering, who studied the dynamics of societal perspectives on water management (Offermans et al., 20II; Valkering et al., 20II), mainly drawing on Thompson et al. (I990). Thompson et al. (I990) developed an extended version of Mary Douglas' so-called Cultural Theory, which describes four archetypical active world views: the hierarchist, the individualist, the egalitarian, and the fatalist view. Key elements in these world views are the beliefs held regarding human nature and physical nature, and the relationship between human needs and natural resources. Van Asselt et al. (I995) made a further distinction between 'world view' (how the world is seen) and 'management style' (how the world should be managed), and defined a 'perspective' as the 'perceptual screen through which people interpret the world and which guides them in acting' (Van Asselt, 2000). Thus, in each of the archetypical perspectives, there is a consistent relationship between world view and management style (Table I). In the hierarchist perspective, regulation of both humans and nature is essential to manage scarcity and risk. The rules should be set by governments, advised by scientific experts. The individualist perspective is characterized by optimism regarding the availability of natural resources and human ingenuity to deal with scarcity and risk. People should be given the freedom to pursue personal profit, and competition will result in innovative, efficient solutions. In the egalitarian perspective, nature is seen as vulnerable and the preferred management style is therefore preventive and risk averse. As everyone's interest and contribution count, cooperation and participatory management approaches are favoured. The fatalist, finally, sees humans as unreliable and nature as unpredictable. The fatalist perspective is therefore characterized by scepticism, indifference and acceptance of risks, and no particular management style is preferred. This classification of perspectives based on Cultural Theory ('CT perspectives') has been frequently and successfully applied to describe and analyse the diversity of societal views on environmental issues and natural resource management (Buck, I989), including water management (Hoekstra, I998; Middelkoop et al., 2004) and climate change (O'Riordan and Jordan, I999; Pendergraft, I998; Verweij et al., 2006). The elements of the CT perspectives (Table I) correspond well 


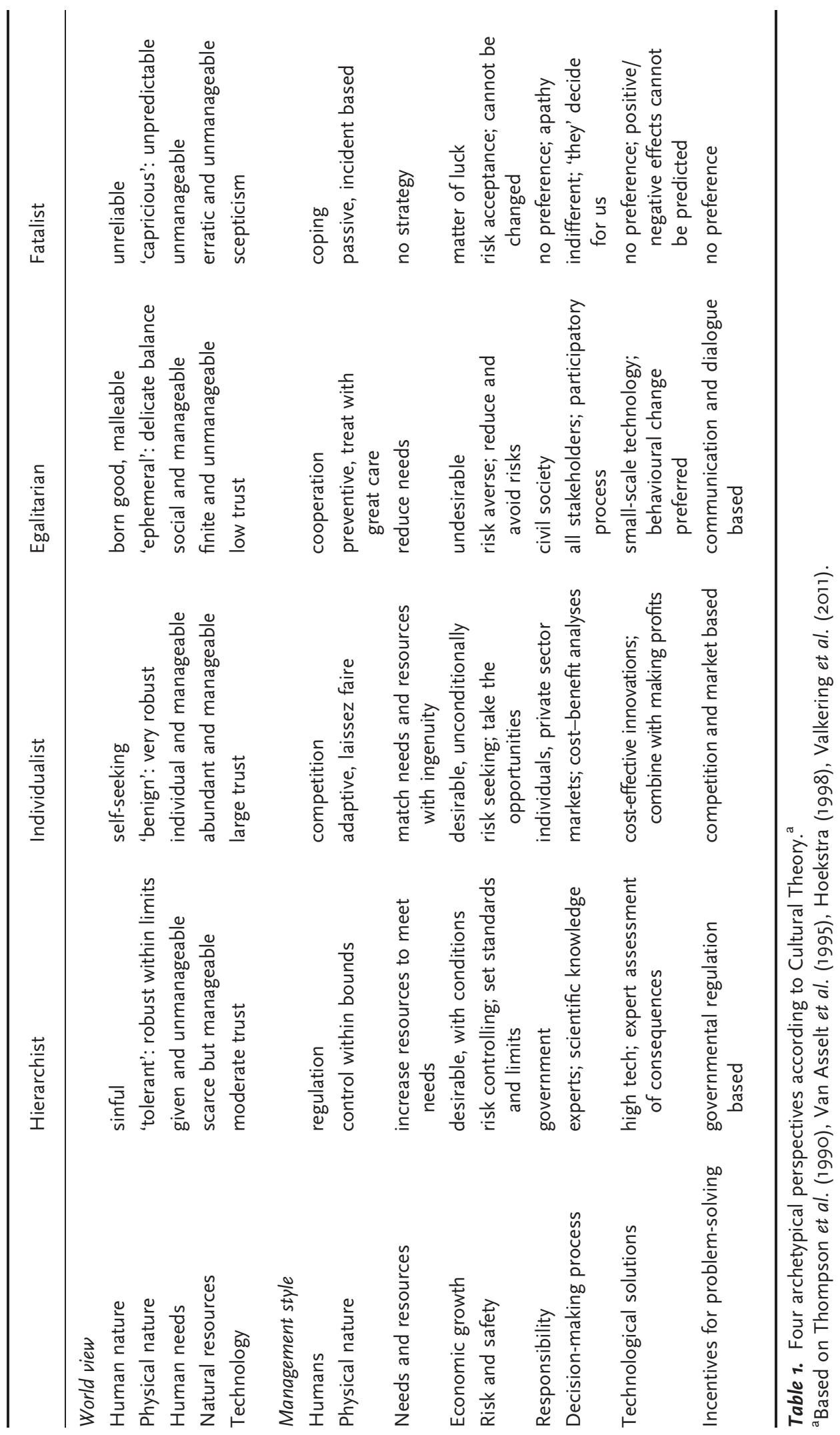


to those we distinguish in our definition, i.e. the stakeholder's perspective on the nature of the problem, the risks involved, the preferred strategies or measures to solve the problem and deal with risk, and the distribution of responsibility for the problem and its solution. The CT perspectives have been criticized for lacking an empirical basis, as people rarely appear to take a consistent and 'pure' CT perspective containing all the typical beliefs (see, e.g., Grendstad and Selle, 2000). However, Offermans (2012) has demonstrated that 'real world' stakeholder perspectives on water management can be adequately described as combinations of beliefs from the various CT perspectives, using these perspectives as reference points for an entire spectrum of 'real' perspectives. In the next section we will present a stepwise method to apply this approach to measure social learning as a convergent change in perspectives.

\section{Measuring Social Learning}

The method we present to measure social learning in participatory approaches to natural resource management is based on the premise that the individual perspectives of participants can be described with a set of beliefs based on the archetypical CT perspectives. The method consists of three steps: operationalization of the CT perspectives for a specific context in a 'perspective scoring table', applying the scoring table as a tool for repeated measurement of the perspectives of participants, and analysis of changes in perspectives.

\section{Construction of a Perspective Scoring Table}

To operationalize the four CT perspectives presented in Table I for a specific natural resource management problem and participatory process, we first need to determine the problem domain, the salient issues and the geographic or administrative scale at which the specific problem is addressed by the participants. Analysis of reports, sometimes supplemented by interviewing experts and/or stakeholders, usually suffices to provide this kind of information. With the information, we can select the most relevant elements of world view and management style from Table I and tailor the generic beliefs of each of the four perspectives to the specific problem context. This results in a table with a set of context-specific issues as rows and the four CT perspectives as columns, with the cells containing the perspectivespecific beliefs. The next step is to 'translate' the rather abstractly worded beliefs into concrete statements that reflect the vocabulary of the domain and the participants. These statements can be obtained by interpretive analysis of problemspecific reports and/or transcriptions of stakeholder interviews or discussions, classifying and coding relevant statements into one of the four CT perspectives. In cases when no statement representing a perspective-specific belief is found, this belief can be translated into a concrete statement with the help of the statements found for the other perspectives. To reduce researcher bias, the translation of beliefs into concrete statements is best done by at least two researchers, for example with an inter-evaluator reliability test. In this test, a second researcher repeats part of the interpretive analysis. The degree to which the interpretations of statements of both researchers match is called the inter-evaluator reliability. The minimum acceptable reliability level is about $80 \%$. A less time-consuming approach to reduce bias is to have the statements as interpretations of CT beliefs checked by two or three other researchers. The end result is a 'perspective scoring table': a table with statements on salient issues representing the CT perspectives with which participants can agree or disagree. Before use, the labels of the CT perspectives should be removed and the statements on each row must be randomized to reduce bias.

\section{Measurement of Perspectives}

The perspectives of participants can then be measured with the perspective scoring table as follows. Participants are asked to mark the statements in the table with which they agree, and are allowed to mark more than one statement per row. This results in a 'score' for each of the CT perspectives: the number of statements a participant agrees with that represent beliefs specific to a particular CT perspective. For example, using a perspective scoring table with Io rows, a participant may exclusively agree with statements representing hierarchist beliefs, which results in a score of Io for the hierarchist perspective and a score of $\circ$ for the other CT perspectives. However, in most cases participants agree with statements that represent beliefs specific to two or more CT perspectives, resulting in a mixed score. The individual perspective of a participant can in any case be described with the scores for each of the CT perspectives, constituting a four-dimensional vector. By repeating the measurement with the perspective scoring table at several instances during the participatory process, changes in the perspectives of participants can be assessed, both in terms of the specific beliefs they endorse and in terms of their scores per CT perspective. 


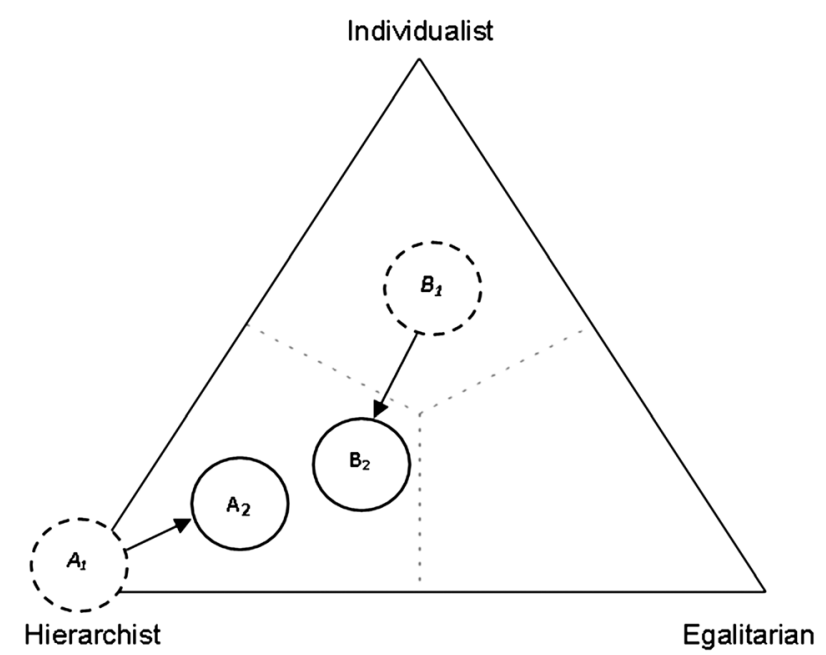

Figure 1. Visualisation of the position of two individual perspectives (of $A$ and $B$ ), relative to three CT perspectives (corners) and each other, as measured at two points in time $\left(A_{1}\right.$ and $A_{2}, B_{1}$ and $\left.B_{2}\right)$.

\section{Analysis of Changes in Perspectives}

The (individual) perspectives and changes therein can be visualized by positioning them in a space spanned by the CT perspectives. For example, Valkering et al. (20I2) use a triangle spanned by the hierarchist, individualist and egalitarian perspectives at the corners (Figure I). The position of a particular perspective is determined by its scores for these three CT perspectives, which are normalized and plotted in so-called barycentric coordinates as a point in the triangle. If the fatalist perspective is also included in the measurement, the triangle can be expanded into a three-dimensional tetrahedron with four corners (Offermans, 20I2). The advantage of visualization is that it provides a quick and easy-to-grasp insight into the positions of the participants' perspectives relative to the various CT perspectives and relative to each other. Moreover, when repeated measures of perspectives are depicted in the same figure, the overall direction of change in perspective can be rapidly assessed and communicated. For example, in Figure I, the perspectives of A and B have become less 'pure' hierarchist and individualist respectively, and, at the same time, the distance between the two perspectives has decreased. In other words, the perspectives of A and B have converged. The distance between two or more perspectives can also be expressed numerically, by calculating the percentage agreement. Agreement is calculated as the number of statements with which all participants agree, relative to the total number of statements with which one or more participants agree, expressed as a percentage. For example, in the case of a measurement with a perspective scoring table consisting of 40 statements (Io issues $\times 4$ CT perspectives), there may be 30 statements with which one or more participants may agree. When, out of these 30 statements, there are six statements with which all participants agree, the percentage agreement is $20 \%$. An increase in the percentage agreement between repeated measurements indicates a convergent change in perspectives. The next step in the analysis is then to assess the changes in perspectives in more detail by comparing the perspective scoring tables from the repeated measurements. This will reveal how exactly the beliefs of the participants have changed and on what specific issues they have reached more agreement. Graphical analysis of perspective change, calculation of percentage agreement and assessment of changes in beliefs will thus provide evidence whether social learning (as we defined it) has occurred or not, and to what extent.

\section{Example 1: River Management in the Context of Climate Change}

\section{Case Description}

The first example to illustrate our method to measure social learning is from the domain of water management. It concerns a Dutch project on river management in the context of climate change. ${ }^{\mathrm{I}}$ In this project, sessions with a

${ }^{\mathrm{I}} \mathrm{http}: / /$ www.deltares.nl/en/product/1518666/sustainable-delta-game. 
serious game were organized with a wide range of professionals from the water management sector (see for an extensive description Valkering et al., 20I2). The aim of the sessions was to explore possible climate adaptation pathways in river management and, ultimately, to identify sustainable strategies that are both flexible and robust to changing climatic and societal conditions. During these 3 hour game sessions, the participants had to manage a typical Dutch river basin over a period of Ioo years under a transient scenario of climate change. The climate scenario determines the timing and frequency of discharge peaks and water levels in the river. A computer model calculates the combined consequences of water levels and river management strategy for risk of flooding and damage to houses and agriculture, shipping suitability and nature development in the river basin (Haasnoot et al., 20I2). In each session, the participants were distributed over two teams, which had to negotiate and choose a joint strategy, i.e. a set of river management measures to be implemented. In four steps of 25 years, the participants were confronted with the performance of the chosen strategy and had to decide on the strategy for the next 25 years. The game sessions were concluded with a debriefing discussion on the game itself, the dynamics of the session and the lessons learned.

\section{Measurement of Social Learning}

To measure the perspectives of the participants, a perspective scoring table was developed for the specific domain and scale of the problem, given the salient issues in the Dutch debate on river management (Table 2). Relevant issues were selected and perspective-specific beliefs were formulated and translated into concrete statements on the basis of workshops with water professionals and interpretive analysis of historical studies of river management. The inter-evaluator reliability in the development of the table with the statements was 92\% (Offermans and Cörvers, 20I2). Note that, in this perspective scoring table, the fatalist perspective was not included. For water managers, the fatalist perspective was considered irrelevant, given the 'passive' nature of this perspective and the lack of preference for a specific management style (Offermans and Cörvers, 20I2).

Before the start of a game session, the participants were asked to fill out the (randomized) perspective scoring table. Based on their individual perspectives, the participants were distributed over two teams, each consisting of more or less like-minded members. The teams then again determined, as a group, their positions in the perspective scoring table. This yielded the first measurement of the team perspectives. After each round in the game, the teams were asked to review their positions in the perspective scoring table. Changes in position, if any, were recorded.

The results of a typical session are depicted in Figure 2. This session was organized at the Dutch Water Service, a governmental centre of expertise on water management, and the Io participants came from a variety of positions and departments within the service. The locations of the team perspectives in the triangle show that initially the teams had quite distinct perspectives. One team perspective could be characterized as predominantly hierarchist, the other team as predominantly egalitarian. However, at the end of the game session, the distance between the two team perspectives had decreased and both teams had become predominantly hierarchist in perspective. The percentage agreement between the teams increased from 42 to $47 \%$. Obviously, the perspectives of the team have converged during the game session, and thus, according to our definition, social learning has occurred. A comparison of the perspective scoring tables at the start and at the end of the game session revealed that the additional statements they agreed all on were mostly from the hierarchist perspective. This resulted in more agreement on the role and risks of technological measures in river management and on how to deal with safety and risk of flooding. In fact, both teams added rather than switched positions in the perspective scoring table, and thus 'expanded' their perspectives.

\section{Example 2: Agricultural Land Use under Climate Change}

\section{Case Description}

Our second example is from the domain of agriculture, and concerns a project on adaptation strategies for agricultural land use to climate change in the Dutch province of Flevoland (Wolf et al., 20I2). In this project, models were developed and applied to provide quantitative insights into the interactions between climate and market changes, 


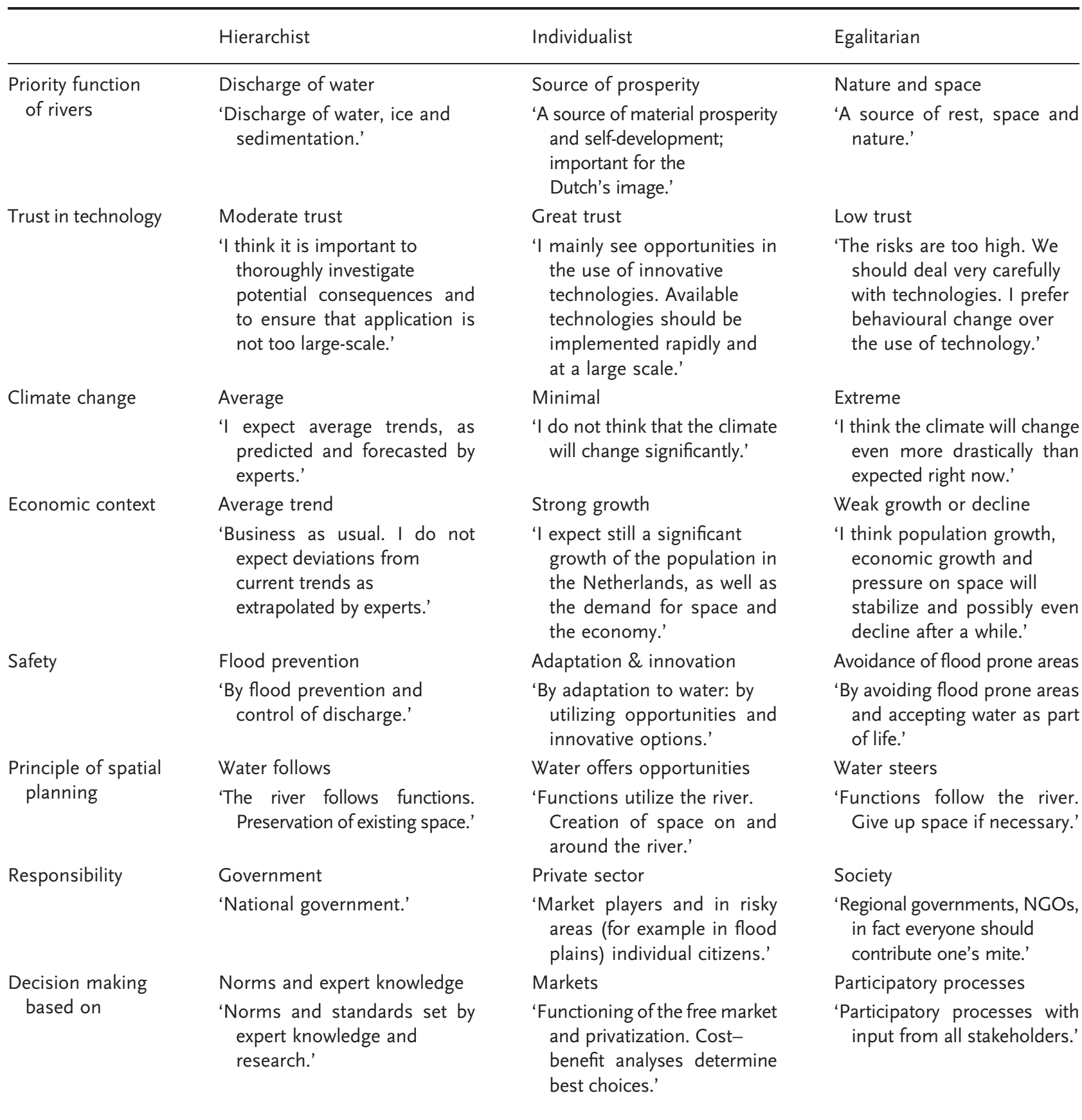

Table 2. Perspective scoring table with CT perspectives on river management in the context of climate change. Cells contain perspectivespecific beliefs and corresponding statements. After Offermans and Cörvers (2012) and Valkering et al. (2012). These authors call this a perspective map.

crop responses and adaptation options. Stakeholders were involved in the project to assess the potential adaptation measures, the support for these measures among the stakeholders, and the likelihood that the measures would be implemented. These stakeholders included individual farmers and representatives of the regional farmers' organization, regional water board and provincial government. In a series of five workshops, scientists and stakeholders discussed the specific conditions and developments in the region and possible climate change impacts, as well as 


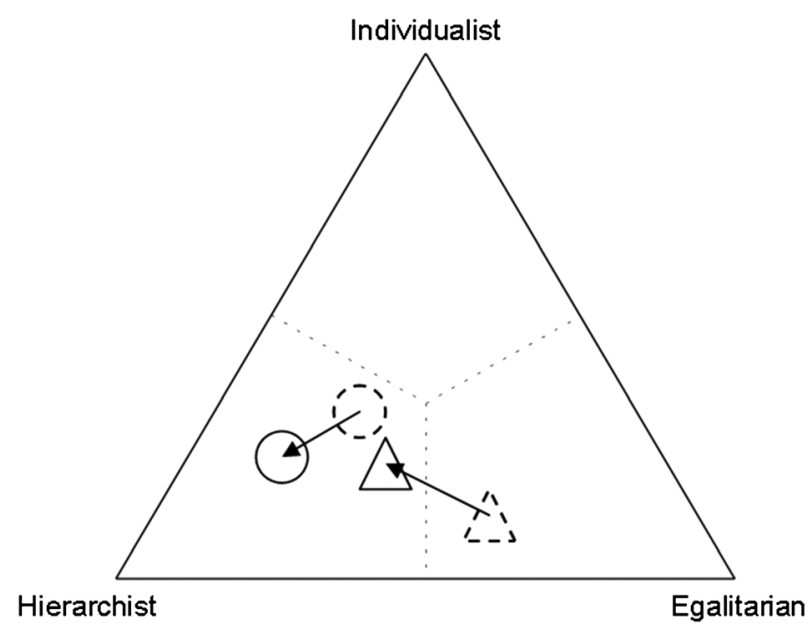

Figure 2. Visualisation of the position of the perspectives of two teams playing the river management game, as measured at the start (symbols with dotted lines) and at the end of the game (symbols with drawn lines)

potential adaptation strategies (see for details Schaap et al., 20IIa). During the final workshop, the perspectives of the stakeholders were measured, the results of which are presented below.

\section{Measurement of Social Learning}

To measure the perspectives of the stakeholders, a scale- and domain-specific perspective scoring table was constructed (Table 3). Relevant issues, e.g. water scarcity, were selected and perspective-specific beliefs were formulated on the basis of information from project meetings, reports and studies (see, e.g., Schaap et al., 20Irb; Mandryk et al., 2012), and interviews with five individual farmers. The generic beliefs in the table were translated by the first author into concrete statements using transcripts of the farmer interviews and the discussions during a previous stakeholder workshop. These statements were independently checked by three other researchers, which resulted only in minor alterations.

At the start of the final workshop, the stakeholders were asked to fill out the perspective scoring table. As two out of the five attending stakeholders were late, they were excluded from the measurements. The remaining three stakeholders were two farmers who were also board members of the regional farmers' organization or the regional water board, and an employee of the regional farmers' organization. At the 3 hour workshop, researchers presented modelling results of possible climate change impacts and adaptation measures at crop and farm level. During and after each presentation many questions were asked by the stakeholders and their concerns were extensively discussed. The discussion focussed on which steps to take for a climate-proof agriculture in the region and the usefulness of the presented results for that purpose. At the end of the meeting, the stakeholders were asked to review their initial positions in the perspective scoring table.

The results, which were also presented and discussed at the very end of the stakeholder meeting, are shown in Figure 3. The initial perspectives of the three stakeholders were not very distinct: stakeholder A had a slightly more hierarchist perspective, stakeholder B's perspective was a perfect balance of hierarchist, egalitarian and individualist beliefs and stakeholder $\mathrm{C}$ was even more balanced, with equal scores for all four CT perspectives. After the session, stakeholder A had become a bit more egalitarian and B slightly more individualistic in beliefs, whereas C's position remained unchanged. Overall, the distance between the perspectives had not markedly changed. However, the percentage of statements on which all three stakeholders agreed increased from 29 to $34 \%$, indicating, according to our definition, that social learning had occurred. A comparison of the perspective scoring tables at the start and at the end of the meeting revealed that the additional statements on which they all agreed concerned egalitarian beliefs regarding the issue of responsibility and the preferred type of incentive for problem-solving. As in the previous example, the stakeholders added rather than switched positions in the perspective scoring table, and their perspectives became (even) more balanced. 


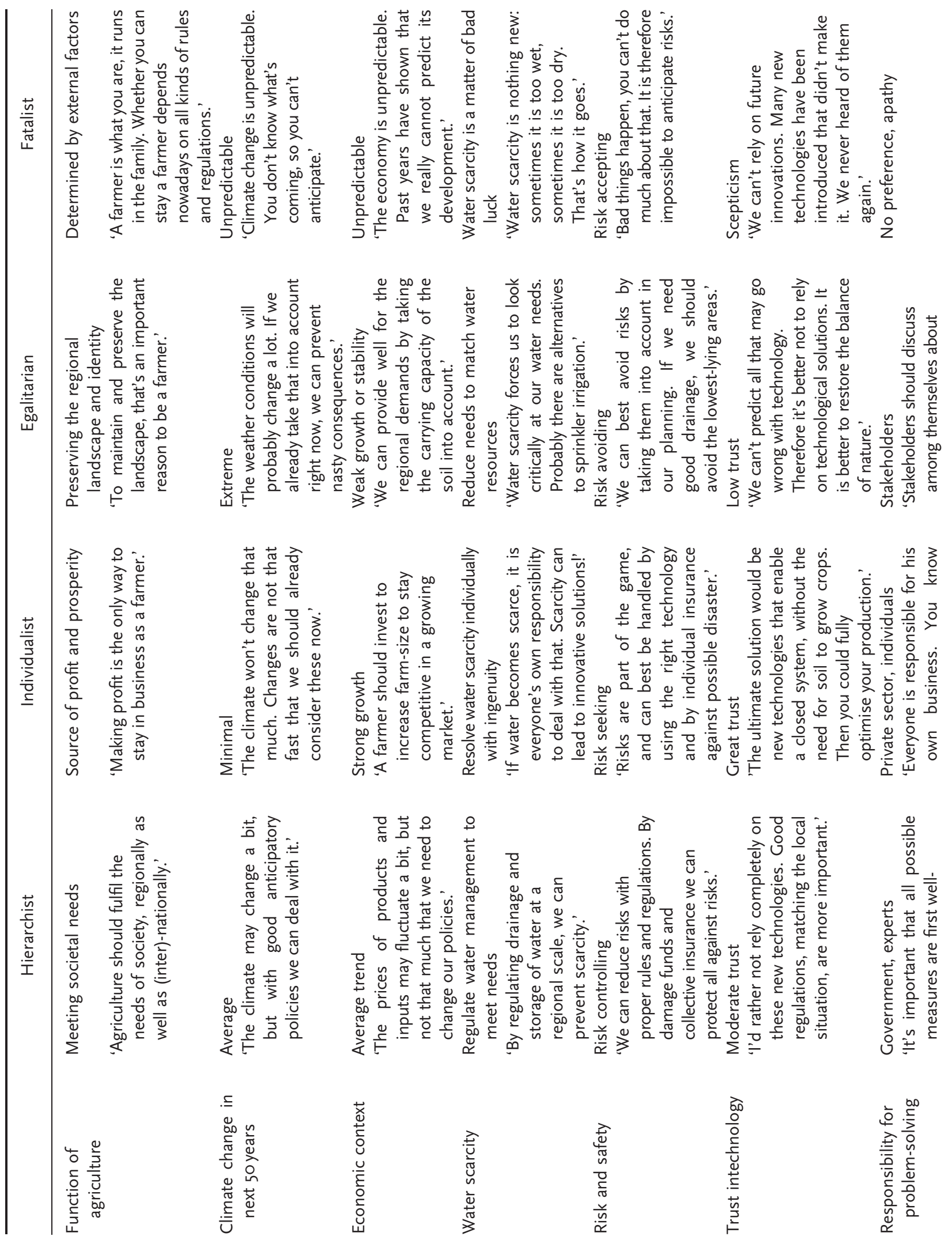




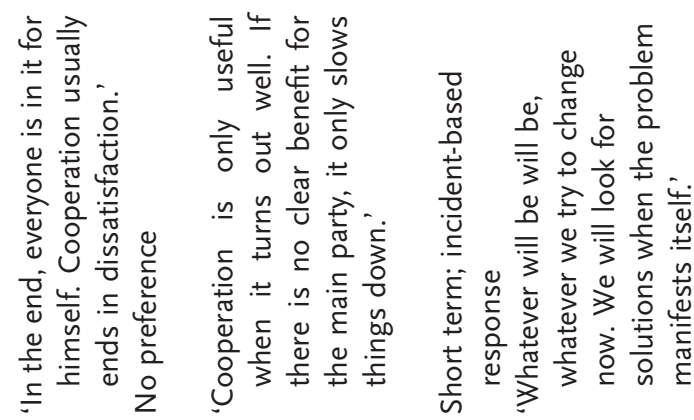
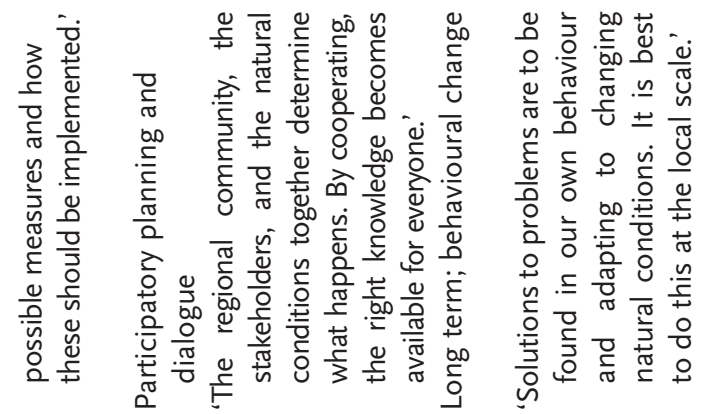

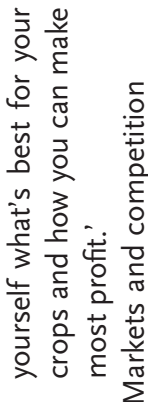
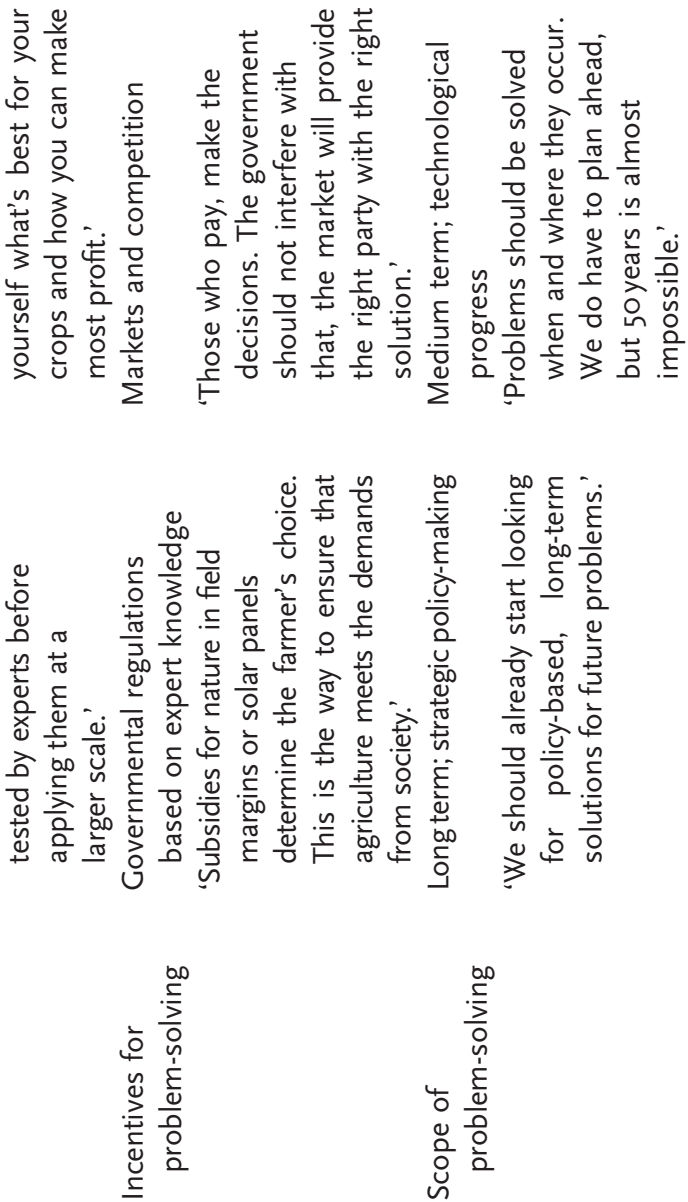

Env. Pol. Gov. 24, 1-15 (2014) 


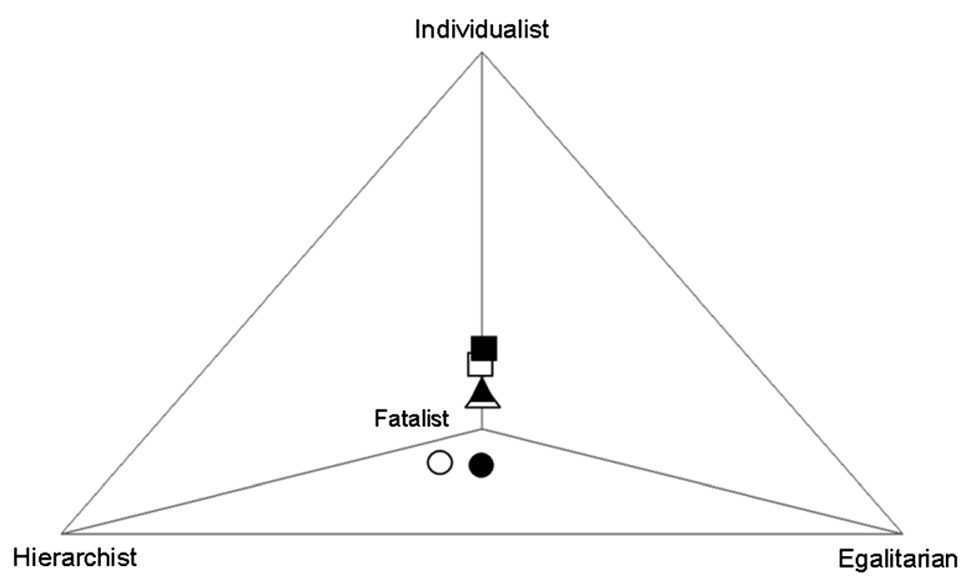

Figure 3. Visualisation of the position of the perspectives of three stakeholders, as measured at the beginning (white symbols) and at the end (black symbols) of the workshop on agriculture and climate change

\section{Discussion and Conclusions}

The role of social learning as a governance mechanism in natural resource management has been frequently highlighted over the past decade. However, progress in finding evidence for this role and gaining insight into the conditions that promote it are hampered by the lack of clear, operational definitions of social learning and practical and reliable methods to measure it in the context of participatory approaches (Reed et al., 20I0). With the presented method, the occurrence and extent of social learning can be assessed by measuring the perspectives of individual stakeholders, the diversity as well as the agreement in perspectives at group level and the changes therein over time. The method yields measurements of social learning that are visual (positions in graph), as well as quantitative (change in percentage agreement) and qualitative (changes in beliefs). As illustrated by the two examples, the method is flexible in that it can be applied to diverse problems and domains of natural resource management and context-specific perspective scoring tables can be developed with high reliability. As a method to measure stakeholder perspectives and perspective change, its reliability was supported in the reflective discussions at the end of the participatory sessions: in the presented examples as well as in about 20 other sessions with the river management game, the participants recognized and confirmed their initial positions and the changes therein.

The method has several advantages over self-reporting of learning, which is often used to assess social learning in natural resource management (e.g. Blackstock et al., 2007; Schusler et al., 2003). First of all, it is quantitative and much less subjective. A problem with self-reporting is that people are often not aware of (all) changes in their knowledge and views, and a more evidence-based evaluation of learning is required (Tuinstra et al., 2008; Van de Kerkhof and Wierczorek, 2005). Second, the method allows for rapid assessment of and feedback on social learning within participatory sessions. Valkering et al. (2OII) developed a simple computer tool to process perspective scoring tables, enabling rapid visualization of perspective diversity and change, calculation of percentage agreement and comparison of scoring tables. In both the presented examples, visualization was used as input for a reflective discussion on (change in) perspectives at the end of the session. As indicated earlier, such a collective reflection on explicated perspectives can be expected to stimulate social learning. In this way, the method is useful not only for researchers as an analytical tool to study social learning, but also as a facilitation tool for practitioners to promote social learning. By thus stimulating the convergence of perspectives among stakeholders in natural resource management issues, practitioners can enhance the effectiveness and efficiency of participatory decision-making on problems that require a collectively supported strategy. In using the method as a facilitation tool, one should be aware that convergence of perspectives in terms of scores for the CT perspectives may differ from convergence in terms of percentage agreement on specific statements. In the two examples, the percentage agreement increased in both cases by $5 \%$, whereas the convergence in terms of CT perspectives was markedly higher in the first example (compare Figures 2 and 3). Both should therefore be taken into account in the analysis and, when the results are fed back to the stakeholders in a reflective discussion on perspective change, changes in agreement on specific statements should preferably be included in the discussion. 
An alternative to measuring stakeholder perspectives with perspective scoring tables is the use of Q methodology (see, e.g., Cuppen et al., 20I0; Cuppen, 20I2). Q methodology differs from our method in two major ways: (I) domain- and problem-specific statements are derived from written or verbal sources without making use of predefined categories; (2) participants are asked to rank-order all statements (up to 6o) on a scale of agreement, according to a forced normal distribution. A rather complicated statistical analysis then yields sets of statements that represent different perspectives among the stakeholders. Q methodology could be characterized as a 'bottom-up' approach to describing stakeholder perspectives, whereas our method is a combination of 'top down' (Cultural Theory categories) and 'bottom up' (participants may endorse statements from all four categories). The advantage of our method as compared to Q methodology is that it is less time consuming for the participants, and can be conveniently combined with stakeholder meetings that are more content oriented. Moreover, the results can be produced (and fed back) much faster and are easier to understand for non-specialists.

The relative simplicity of our method makes it very practical in use, but brings along several limitations as well. The focus is on the social-cognitive dimension of social learning (beliefs), and the social-relational and behavioural dimensions are not considered. This can be justified when the participatory process has a social-cognitive focus as well, e.g. in participatory integrated assessments (De Kraker et al., 20II). Another limitation is that the statements in the perspective scoring table represent 'only' the archetypical CT perspectives, whereas for example in Q methodology the statements may reveal more subtle existing differences in perspectives among the stakeholders.

The presented method can be applied to measure social learning as an outcome of a participatory process. To determine which process features and context factors foster or inhibit social learning, the method must be combined with in-depth analysis of the communicative interactions between those involved in the process (Muro and Jeffrey, 2008; Reed et al., 2010). For example, in our own investigation of the role of computer models in supporting social learning (De Kraker et al., 20II), we combine this method with content analysis of recorded participatory sessions, direct behavioural observations during these sessions and follow-up interviews of stakeholders after the sessions.

In conclusion, the presented method offers a practical and reliable way to measure social learning, whether it has occurred and to what extent, among stakeholders in participatory approaches to natural resource management. When used in combination with analysis of the communicative interactions between stakeholders, it provides a much-needed analytical tool to increase our understanding of the factors contributing to social learning and how social learning can be facilitated.

\section{Acknowledgements}

We thank our colleagues in the projects 'Perspectives in integrated water resources management in river deltas' (example I) and 'AgriAdapt' (example 2), as well as the participants in the sessions for their cooperation.

\section{References}

Aarts MNC, Van Woerkum CMJ. 2002. Dealing with uncertainty in solving complex problems. In Wheelbarrow Full of Frogs - Social Learning in Natural Resource Management, Leeuwis C, Pyburn R (eds). Koninklijke Van Gorcum: Assen, The Netherlands; $42 \mathrm{I}-436$.

Adger WN, Agrawala S, Mirza MMQ, Conde C, O’Brien K, Pulhin J, Pulwarty R, Smit B, Takahashi K. 2007. Assessment of adaptation practices, options, constraints and capacity. In Impacts, Adaptation and Vulnerability. Contribution of Working Group II to the Fourth Assessment Report of the Intergovernmental Panel on Climate Change, Parry ML, Canziani OF, Palutikof JP, van der Linden PJ, Hanson CE (eds). Cambridge University Press: Cambridge; 7I7-743.

Argyris C, Schön D. 1978. Organizational Learning a Theory of Action Perspective. Addison-Wesley: Reading, MA.

Bandura A. I974. Social Learning Theory. General Learning: Morristown.

Blackmore C. 2007. What kinds of knowledge, knowing and learning are required for addressing resource dilemmas? A theoretical overview. Environmental Science and Policy I0(6): 512-525. DOI: 10.1016/j.envsci.2007.02.007

Blackstock KL, Kelly GJ, Horsey BL. 2007. Developing and applying a framework to evaluate participatory research for sustainability. Ecological Economics 6o(4): 726-742. DOI: Io.IoI6/j.ecolecon.2006.05.014

Bouwen R, Taillieu T. 2004. Multi-party collaboration as social learning for interdependence: developing relational knowing for sustainable natural resource management. Journal of Community and Applied Social Psychology I4(3): I37-I53. DOI: I0.I002/casp.777 
Buck SJ. I989. Cultural theory and management of common property resources. Human Ecology I7(I): IOI-II6.

Collins K, Ison R. 2009a. Editorial: living with environmental change: adaptation as social learning. Environmental Policy and Governance I9(6): 35I-357. DOI: I0.1002/eet.520

Collins K, Ison R. 2009b. Jumping off Arnstein's ladder: social learning as a new policy paradigm for climate change adaptation. Environmental Policy and Governance 19(6): 358-373. DOI: 10.1002/eet.523

Cuppen E. 20I2. A quasi-experimental evaluation of learning in a stakeholder dialogue on bio-energy. Research Policy 4I(3): 624-637. DOI: I0.IOI6/j.respol.20I1.I2.006

Cuppen E, Breukers S, Hisschemoller M, Bergsma E. 20I0. Q methodology to select participants for a stakeholder dialogue on energy options from biomass in the Netherlands. Ecological Economics 69(3): 579-591. DOI: I0.I0I6/j.ecolecon.2009.09.005

De Kraker J, Kroeze C, Kirschner P. 20II. Computer models as social learning tools in participatory integrated assessment. International Journal of Agricultural Sustainability 9(2): 297-309.

Grendstad G, Selle P. 2000. Cultural myths of human and physical nature: integrated or separated? Risk Analysis 20(I): 27-40. DOI: IO.IIII/ $0272-4332.00003$

Haasnoot M, Van Middelkoop H, Van Beek E, Offermans A, Van Deursen W. 20I2. Exploring pathways for sustainable water management in river deltas in a changing environment. Climatic Change II5: 795-8I9. DOI: I0.1007/sio584-0I2-0444-2

Hisschemöller M, Hoppe R. I995. Coping with intractable controversies: the case for problem structuring in policy design and analysis. Knowledge and Policy 8(4): 40-60. DOI: 10.1007/bfo2832229

Hoekstra AY. I998. Perspectives on Water, an Integrated Model-Based Exploration of the Future. International: Utrecht, The Netherlands.

Jiggins J, Röling N, Van Slobbe E. 2007. Social learning in situations of competing clains on water use. In Social Learning: Towards a More Sustainable World, Wals AEJ (ed.). Wageningen Academic: Wageningen, The Netherlands; 4I9-434.

Leeuwis C. 2002. Making explicit the social dimensions of cognition. In Wheelbarrows Full of Frogs - Social Learning in Natural Resource Management, Leeuwis C, Pyburn R (eds). Van Gorcum: Assen, The Netherlands; 39I-406.

Mandryk M, Reidsma P, Ittersum M. 20I2. Scenarios of long-term farm structural change for application in climate change impact assessment. Landscape Ecology 27(4): 509-527. DOI: I0.1007/sio980-0I2-97I4-7

McCrum G, Blackstock K, Matthews K, Rivington M, Miller D, Buchan K. 2009. Adapting to climate change in land management: the role of deliberative workshops in enhancing social learning. Environmental Policy and Governance 19(6): 4I3-426. DOI: I0.I002/eet.525

Middelkoop H, Van Asselt M, Van 't Klooster S, Van Deursen W, Kwadijk J, Buiteveld H. 2004. Perspectives on flood management in the Rhine and Meuse rivers. River Research and Applications 20: 327-342. DOI: 310.I002/rra.I782

Mostert E, Pahl-Wostl C, Rees Y, Searle B, Tàbara D, Tippett J. 2007. Social learning in European river-basin management: barriers and fostering mechanisms from Io river basins. Ecology and Society I2(I). http://www.ecologyandsociety.org/volı2/issi/arti9/ [Accessed 9 December 20Io].

Muro M, Jeffrey P. 2008. A critical review of the theory and application of social learning in participatory natural resource management processes. Journal of Environmental Planning and Management 5I(3): 325-344.

Offermans AGE. 20I2. The Perspectives Method. Towards Socially Robust River Management. International Centre for Integrated Assessment and Sustainable Development (ICIS), Maastricht University: Maastricht, The Netherlands.

Offermans A, Cörvers R. 20I2. Learning from the past: changing perspectives on river management in the Netherlands. Environmental Science and Policy I5(I): I3-22. DOI: I0.I0I6/j.envsci.20II.I0.003

Offermans A, Haasnoot M, Valkering P. 20II. A method to explore social response for sustainable water management strategies under changing conditions. Sustainable Development I9(5): 312-324. DOI: I0.I002/sd.439

O’Riordan T, Jordan A. I999. Institutions, climate change and cultural theory: towards a common analytical framework. Global Environmental Change 9: 8I-93.

Pahl-Wostl C, Craps M, Dewulf A, Mostert E, Tabara D, Taillieu T. 2007. Social learning and water resources management. Ecology and Society I2(2). http://www.ecologyandsociety.org/volı2/iss2/art5/ [Accessed 4 December 2010].

Pahl-Wostl C, Hare M. 2004. Processes of social learning in integrated resources management. Journal of Community and Applied Social Psychology I4(3): I93-206. DOI: I0.1002/casp.774

Pendergraft CA. I998. Human dimensions of climate change: cultural theory and collective action. Climatic Change 39(4): 643-666.

Reed MS. 2008. Stakeholder participation for environmental management a literature review. Biological Conservation I4I(IO): 24I7-243I. DOI: I0.I0I6/j.biocon.2008.07.0I4

Reed MS, Evely AC, Cundill G, Fazey I, Glass J, Laing A, Newig J, Parrish B, Prell C, Raymond C, Stringer LC. 20Io. What is Social Learning? Ecology and Society I5(4). http://www.ecologyandsociety.org/voli5/iss4/respi/ [Accessed 9 December 20IO].

Rittel HWJ, Webber MM. I973. Dilemmas in a general theory of planning. Policy Sciences 4(2): I55-I69. DOI: I0.1007/bfor405730

Röling N. 2002. Beyond the aggregation of individual preferences. Moving from multiple to distributed cognition in resource dilemmas. In Wheelbarrows Full of Frogs - Social Learning in Natural Resource Management, Leeuwis C, Pyburn R (eds). Koninklijke van Gorcum: Assen, The Netherlands; 25-48.

Schaap B, Blom-Zandstra M, Hermans CL, Meerburg B, Verhagen J. 20IIa. Impact changes of climatic extremes on arable farming in the north of the Netherlands. Regional Environmental Change II(3): 73I-74I. DOI: I0.I007/sIoII3-0II-0205-I

Schaap BF, Reidsma P, Mandryk M, Verhagen J, Van der Wal M, Wolf J, Van Ittersum MK. 20Irb. Adapting Agriculture in 2050 in Flevoland; Perspectives from Stakeholders. Climate Changes Spatial Planning. http://promise.klimaatvoorruimte.nl/proi/publications/show_publication.asp? documentid=6I60\&GUID=bo8fed55-7029-4f89-9070-ffege93di7fd [Accessed 3 February 20I2].

Schusler TM, Decker DJ, Pfeffer MJ. 2003. Social learning for collaborative natural resource management. Society and Natural Resources I6(4): 309-326. DOI: 10.1080/08941920390I78874

Thompson M, Ellis R, Wildavsky A. I990. Cultural Theory. Westview: Boulder, CO. 
Tuinstra W, Jäger J, Weaver PM. 2008. Learning and evaluation in Integrated Sustainability Assessment. International Journal for Innovation and Sustainable Development 3(I/2): I28-152.

Valkering P, Van der Brugge R, Offermans A, Haasnoot M, Vreugdenhil H. 20I2. A perspective-based simulation game to explore future pathways of a water-society system under climate change. Simulation and Gaming. http://sag.sagepub.com/content/early/20I2/06/06/ I046878II244I693.abstract [Accessed 4 December 20I2].

Valkering P, Van der Brugge R, Offermans A, Rijkens-Klomp N. 2oII. Scenario analysis of perspective change to support climate adaptation: lessons from a pilot study on Dutch river management. Regional Environmental Change II(2): 229-24I. DOI: I0.IO07/sioII3-0IO-0I46-0

Van Asselt MBA. 2000. Perspectives on Uncertainty and Risk. The PRIMA Approach to Decision Support. Kluwer: Dordrecht.

Van Asselt MBA, Rotmans J, Den Elzen MGJ, Hilderink HBM. I995. Uncertainty in Integrated Assessment Modelling. A Cultural Perspective Based Approach. National Institute of Public Health and the Environment (RIVM): Bilthoven. http://hdl.handle.net/I0029/I0066 http:// www.rivm.nl/bibliotheek/rapporten/461502009.pdf [Accessed 3 September 2007].

Van Bommel S, Röling N, Aarts N, Turnhout E. 2009. Social learning for solving complex problems a promising solution or wishful thinking? A case study of multi-actor negotiation for the integrated management and sustainable use of the Drentsche Aa area in the Netherlands. Environmental Policy and Governance I9(6): 400-4I2. DOI: I0.1002/eet.526

Van de Kerkhof M, Wierczorek A. 2005. Learning and stakeholder participation in transition processes towards sustainability: methodological considerations. Technological Forecasting and Social Change 72: 733-747.

Verweij M, Douglas M, Ellis R, Engel C, Hendriks F, Lohmann S, Ney S, Reyner S, Thompson M. 20o6. Clumsy solutions for a complex world: the case of climate change. Public Administration 84(4): 8I7843.

Wildemeersch D. 2007. Social Learning revisited: lessons learned from North and South. In Social Learning Towards a Sustainable World, Wals A (ed.). Wageningen Academic: Wageningen, The Netherlands; 99-II6.

Wolf J, Reidsma P, Schaap B, Mandryk M, Kanellopoulos A, Ewert F, Van Oort P, Angulo C, Rumbaur C, Lock R, Enders A, Adenauer M, Heckelei T, Rötter R, Fronzek S, Carter TR, Verhagen A, Van Ittersum MK. 20I2. Assessing the Adaptive Capacity of Agriculture in the Netherlands to the Impacts of Climate Change under Different Market and Policy Scenarios (final report AgriAdapt Project Ar9), KvR 059/I2. http://promise. klimaatvoorruimte.nl/proi/publications/show_publication.asp?documentid=72I4\&GUID=fefeooI9-344d-42d4-93a6-Id40f9467368 